\title{
Retailers, Frontiers of Innovation and Local Legislative Constraints"
}

\author{
Vincenzo Tassinari $^{* *}$
}

\begin{abstract}
The role of retail has deeply changed over the last years. Today, large scale retailers are no longer perceived as mere sellers of products.

A modern, advanced retailer, must be able to innovate and enrich the value of the offer throughout its network, integrating more and more goods and services under an umbrella brand that increases distinctiveness and loyalty.

In order to do so, it is necessary to have an entrepreneurial ability oriented towards evolution of demand, a socially-focused company mission, but also a legislative landscape that allows for this innovation process.
\end{abstract}

Keywords: Large-Scale Retail; Global Markets; Supply Chain; Corporate Responsibility; The Coop Italia Case; Private Label; Corporate Responsibility

\section{The Store as the Place of Relation and Service}

The role of retail has deeply changed over the last years. Today, large scale retailers are no longer perceived as mere sellers of products.

Retail space today goes far beyond the sale of goods, to become the place of relationship and contact between the retailer and its customers.

The evolution of stores offer structure itself highlights this trend: from stores distributing only packaged goods to self services, to assisted fresh products counters (first of all delicatessen, meat and fish), to the offer of new services, we see that the main retailers are changing their stores logics towards transactions that are filled with relation and contact with the customer.

This relational dimension is the basis to be constantly enriched and renewed, on which lays the trust between the retailer and its most loyal and high-spending customers (it is well-known that $30 \%$ of customers count for $80 \%$ of the turnover).

A modern, advanced retailer, must be able to innovate and enrich the value of the offer throughout its network, integrating more and more goods and services under an umbrella brand that increases distinctiveness and loyalty.

\footnotetext{
* Invited Article

** Coop Italia, President (info@coopitalia.coop.it)
}

Tassinari Vincenzo, Retailers, Frontiers of Innovation and Local Legislative Constraints, Symphonya. Emerging Issues in Management (symphonya.unimib.it), n. 1, 2010, pp. 18-22 
In order to do so, it is necessary to have an entrepreneurial ability oriented towards the evolution of demand, a socially-focused company mission, but also a legislative landscape that allows for this innovation process, to guarantee the maximum benefit to the citizen-consumer.

\section{Brand Loyalty and Development of Private Label Products and Services}

\subsection{The Key Role of Private Label}

If human relations are a fundamental space to build loyalty, a retailer builds and strengthens its brand equity through the credibility of its private label.

Private label is the main vehicle, practical tool, to translate a retailer's mission into a product offer which includes the benefits promised by the brand to its customers.

In some retail contexts, private label have reached significant market shares, surpassing leader industrial brands in many markets.

Marketing strategies that led to the development of private label vary from Country to Country, based on the competitive landscape and the store formats:

1. in the United Kingdom, where private label today represent over the $40 \%$ of share (source: Planet Retail 2010), the main retailers developed their private label covering both medium and medium-high price positioning.

2. in Spain, the success of private label is much more recent, but today it reaches shares higher than $30 \%$, with a higher focus on good value;

3. in France, where shares have historically been around the $20 \%$, over the last years we see an evolution of private label towards the lower segment/price positioning; this especially as a tool to fight the more recent development of discounters.

In Italy there is still a significant differential with the rest of Europe, even if over the last years the total private labels share has strongly increased, from around $7 \%$ at the end of the' 90 s to the 13,6\% in 2009 (Source: Iri Infoscan).

This more recent development is not always inspired by clear strategic logics and a strong orientation towards consumer's needs.

Except for a few retailers, private labels in Italy have often covered a low offer segment, focused mainly on price, without specific aspects, distinctive of the brand.

Other retailers followed a different way, that of a low price offer, but with value for customers.

With its private label, Coop was the first company in Italy to develop a wide and diversified offer of food products, and over the last years, also non food products.

This constant commitment represents today a market share of Coop private label equal to the $25 \%$ in food, thanks to a selective offer, with categories and products where the "values" of cooperation can really emerge.

The heart of retailers private label offer has always been the protection of customers purchasing power, through the development of products with guaranteed quality and a fair price. The subject of quality is constantly linked to high attention in the selection of suppliers, bound by strict controls on raw materials and manufacturing processes, on environmental protection and work conditions. 
Coop, consistently with the logics of the most modern and advanced global markets, has developed in addition to its core brand, additional sub-brands to address consumers new needs, from organic to fair trade, to premium, high quality products.

This is the strategic role that retailers can play with their private label: to provide their customers with a wide, articulate offer of products, corresponding to needs in constant evolution, but always inspired by safety, reliability, social and environmental responsibility of the whole supply and distribution chain.

This is the winning approach that allows private label to overcome once and for all its inferiority complex with respect to big leader brands and to be a brand among brands. The direct expression of the credibility that a retailer builds every day in its stores.

\subsection{Retailers Brand as a Guarantee for the Development of New Services}

Retailers who want to maintain their market leadership and increase their customers loyalty in time must face a crucial question.

Is it enough to develop their own brand only limited to food products or is it necessary to play on a wider field, that exploits their stores network and the loyalty patrimony achieved through time at best, to provide customers with more services?

The answer we see at a global level is quite clear.

The main global and national leader retailers are following the road to innovation and offer differentiation, introducing new services of different sectors in their activity portfolio.

British culture is the most advanced in this sense. British retailers are among the most advanced in the extension of the products/services portfolio.

Tesco has always been the most innovative retailer (back in 2000 it already offered a complete line of financial services for people), today reaching significant results in the services area: in 2010 Tesco plans to get around $1 \mathrm{Bln}(\mathrm{GBP})$ of profits, including the services of Tesco Mobile, Tesco Bank and Tesco.com. In the pharmaceuticals sector, Tesco expects to further improve the 2009 turnover of $389 \mathrm{Mln}$.

British cooperation is no less. $30 \%$ of the Co-operative Group's turnover and $35 \%$ of its profits are generated in the services area: from legal consulting to insurances, from laundry and tailoring services to pharmacies, travel agencies and telecoms.

Auchan and Carrefour, whose core business is with hypermarkets, have used services to enrich their offer and to support the relaunching of a store format which underwent a slowdown after years of great success:

- Auchan has around 3 million customers in financial services, thanks to its formula Banque Accorde; while for mobile telephony it has around 5 million active users

- Carrefour's 2009 turnover in the financial sector was around 281 Mln $(€)$, with an increase of $11 \%$ vs the previous year. In the 
pharmaceuticals sector, its 2009 turnover was around $530 \mathrm{Mln}(€)$; it continues to develop mobile telephony services in partnership with Orange mobile.

In Germany, Aldi has launched Aldi Talk, a mobile phone service with around 2,7 million users.

\subsection{The Coop Italia Case: Non-Liberalizations as Restraints to Innovation for Large Scale Retail}

Italian retail market suffers from a legislative landscape which has not favoured a modern integration of goods and services trade, like other European experiences.

A recent research (Prometeia, 2010) estimates a potential of 23 Bln Euros, equal to the $1,4 \%$ of GDP that could be generated through liberalization of some sectors such as petrol distribution, financial and insurance services, a higher liberalization of food and non food trade.

The liberalization process would favour the development of new activities and, as a consequence, of employment, improving purchasing conditions of many goods for Italian citizens.

Coop is among the first promoters of this way, which in Italy is bristling with difficulties, due to national protectionist if not corporative rules.

In the field of parapharmaceuticals, Coop has operated in the small opening allowed for by the present legislation, only for over the counter products, developing pharmacy corners in its stores, named Coop Salute (Coop Health): 93 corners, with a turnover of $70 \mathrm{Mln}$ Euros, equal to more than $65 \%$ of the total retail turnover in this sector. Customers saved 12,7 Mln Euros (around 29\%) compared to the purchase of the same products in traditional pharmacies.

Other national retailers did not believe in the opportunities of parapharmaceuticals, either not entering this market or making only limited investments.

Coop is the only retailer who translated its commitment to this sector, not only by opening pharmacy corners, but also by producing two important over the counter pharmaceuticals under its private label, allowing consumers to save over $60 \%$ compared to the equivalent products sold in pharmacies.

Also in the sector of mobile telephony, CoopVoce was the first case of success of a virtual operator in Italy. CoopVoce, using the sales network of supermarkets and hypermarkets, offers a good value, essential and reliable service, which today counts 500.000 customers, with the target of doubling the number of users.

The other virtual operators, except for Poste italiane, have reached only marginal shares or even left this market.

These are important results, but only small steps if compared with the figures we saw in other European Countries.

There is still a lot to do to open up other markets such as banking or petrol distribution to more competitive forms of offer: these are the sectors where lack of transparency of the offer and increase of prices caused a worsening in consumer satisfaction.

The European Community we live in today is almost totally monetary and financial; but we are going to be part of the Community of European Consumers; 
Berlin consumers will look at Paris and Madrid consumers and others; Italian consumers will look at them and understand that they are paying higher prices for primary services. The questions that will arise from this new scenario will need effective answers. 